\title{
既設揚水発電所における \\ 揚水・発電同時運転に関する水理検討 \\ HYDRAULIC STUDY ON THE SIMULTANEOUS OPERATION AT AN EXISTING PUMPED-STORAGE HYDROELECTRIC PLANT
}

\author{
田岡洋 1 河内友一 $2 \cdot \lambda^{2}$ 江彰 $^{3} \cdot$ 吉岡一郎 4 - 佐藤隆宏 5 \\ Hiroshi TAOKA, Yuichi KOUCHI, Akira IRIE, Ichiro YOSHIOKA and Takahiro SATO \\ 1非会員 工修 中国電力株式会社流通事業本部 ( $7730-8701$ 広島市中区小町 4 番33号)

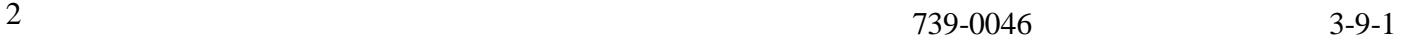 \\ 3 正会員 博士 (工学) 中国電力株式会社流通事業本部（广 680-0812 鳥取市新品治町1番地2）。 \\ 4正会員 工修 中国電力株式会社流通事業本部 (下 730-8701 広島市中区小町 4 番33号) \\ 5 正会員 工修 電力中央研究所地球工学研究所流体科学領域 (
}

\begin{abstract}
Generally, pumped-storage hydropower plants with constant speed type can change generating power in order to maintain the frequency of electricity grid, provided that turbine mode is selected. However, the existing pumped storage plant with this type can control the power evacuated to the grid even in the pumping mode just by adopting simultaneous operation. In the operation, some units are in turbine mode and others in pumping mode. In this paper, hydraulic problems, which were not considered in the design stage, in the simultaneous operation of the existing pumped storage hydropower plant, such as surging, water hammer pressure and head loss at the branch are examined. It is confirmed that these problems wouldn't affect the possibility of the simultaneous operation.
\end{abstract}

Key Words : pumped-storage hydroelectric plant, frequency control, surging, water hammer pressure, head loss

\section{1.はじめに}

電力の品質は , 一般的には , 停電せず継続供給するこ とができる度合い，電圧を規定值どおり維持できる度合 い, 周波数を規定值どおり維持できる度合いという3つ の指標をもって説明される1) . 停電が日常生活に大きな 影響を与えるのは周知のことであるが, 電圧の変化か大 きいとモーターを使用した機器の故障や冷蔵庫などイン バーターを使用した機器の発熱などか発生する . 周波数 か変化すると工場のモーターの回転速度か変わるなどし て，工業製品の品質のばらつきなどの影響か生じ，光の 程度が大くなると発電所にも影響力出て停電力発生す る可能性もある. 電力の需要は常に変化していることか ら，品質を安価に確保するために設備や運用の面で樣々 な工夫がなされているが, 㫕のうちのひとつとして大き な役割を担っているのが, 大型の揚水発電所である .

揚水発電所の主たる役割" ${ }^{2}$ は, 需給均衡の維持, 発電 費用を抑える経済運用への貢献などである.特に後者に
おいては, 揚水を行うケースとして , 火力か経済運用す るため完全に停止しない最低出力て運用しても供給力が 需要を上回る場合 (下げ代対策) や, 深夜や休日などに 安価な電源て揚水すれば効果がある場合などがあるほか， 発電の目的によっては周波数調整用, 系統運用対策など のために稼動することもある .

揚水発電所の型式は, 発電用の水車・発電機と揚水用 のポンプ・電動機を別々に設置する「別置式」，発電用 水車，揚水用ポンプ，発電電動機を設置する「タンデム 式」，水車とポンプの機能をあわせ持ったポンプ水車と 発電電動機を設置する「ポンプ水車式」の3 種類に分類 される.我力国で最初の揚水発電所として1934年に運転 を開始した小口川第三発電所 (別置式) と池尻川発電所 (一部タンデム式) は, 豊水期に水を汲み上げ渴水期に 発電をするものであつた . 兴の後, 1960年頃以降電源構 成の変化, 昼間に生じる1日の需要変動におけるピーク に対応する電源の必要性などから，現在の揚水発電所の 大半を占める大型のポンプ水車式のものか開発されるよ うになっだ゙. 1980年頃より夜間でも需給バランスの微妙 
な調整の必要性か甡じてきたことから，揚水時にも周波 数を調整する機能力求められるようになった . 乥れまで の国内の一般的な揚水発電所のポンプ水車・発電電動機 は定速機であり，発電時には周波数調整か可能であるが， 揚水運転中には周波数を調整する能力はなかった .これ を解決するものとして , 揚水時の入力電力を調整できる ポンプ水車式可変速揚水発電システムカ潤発され, 大河 内発電所において採用された4). 最近ては，奥多々良木 発電所"のように, 既存の定速機の揚水発電所を可変速 システムへ変更する例もみられるようになつたが，この 場合は発電機周辺に励磁装置等の設置スペースカ新たに 必要になるなど, 多額の工事費が必要である.

欧州では, オーストリアのKOPSII 発電所のようにタン デム式の揚水発電所において揚水と発電を同時に行なう こと (以下，「揚水・発電同時運転」) により，揚水時 における周波数調整を実施している発電所の例も見られ るようになつたの) . 同樣な同時運転を既設の定速機のポ ンプ水車式揚水発電所において実施することができれば， 大きな費用を投じて可変速システムへ更新することなく 可変速システムと類似した機能を確保することができる． しかしながら，产のような実施例や検討はなく，既存水 路設備における水理的な課題も明らかになっていない .

そこで, 本稿で , 揚水・発電同時運転を想定せずに 設計・開発された複数台のポンプ水車 (定速機) を持つ 揚水式発電所において, 揚水運転中に少なくとも1台を 自動周波数調整発電 (以下，「AFC運転」) で同時運転 し, 周波数調整機能を持たせた場合の水路内の水理的な 課題につてて検討した結果を報告する．

\section{2 . 対象とした揚水発電所}

本検討て対象とした揚水発電所は, 上池と下池の間を 約 $6 \mathrm{~km}$ の水路系て結ばれ，有効落差 $489 \mathrm{~m}$, 最大使用水量 $300 \mathrm{~m}^{3} / \mathrm{s}$ ，最大出力 120 万 $\mathrm{kW}$ である. 対象とした揚水発 電所の諸元を表-1に , 概要图を図-1に示す . 上池取水口 からサージタンクまでは約 $3.4 \mathrm{~km}$ の導水路トンネルで結 ばれており，サージタンクのすぐ下流にY分岐部がある . Y分岐後に約 $1 \mathrm{~km}$ の水圧鉄管を経て再度分岐し4台の水車 八導水される.水車と下池は2本の放水路により結ばれ ており，光れ光れの放水路の途中に調圧水室を有してい る.現状では,この発電所においては発電時にのみ周波 数調整のためのAFC運転を行っている.

\section{3 . 同時運転の概要と水理的検討の内容}

揚水・発電同時運転を実施した場合の水路内の流れの 状況を図-1にあわせて示す . 図-1に示した流れ状況は 1,2 号機において揚水運転を，3,4号機において発電運転
を実施した場合のものである .このような同時運転によ る周波数調整の方法は図-2に示すとおりであり，定速機 による揚水と同時に，発電側でAFC運転を行い，兴の入 出力の差分により，結果的に揚水時において $\mathrm{AFC}$ 運転を 行うものである .

図-1に示すような水路内流れの状況，とくにY分岐部 の流れの方向は建設時の設計では考慮されていない，关 こで，同時運転の実施可否を判断するための水理的な検 討課題として表-2に示す 8 項目を取り上げた . 今回の検 討は可能性検討の段階であるため，表-2の8項目のうち， 最も基本的な課題である(1) (3)の3項目について検討す ることとし , (4)〜8)の5項目については今後の課題とし た .また，同時運転の組み合わせとしては，1号機揚水， 2 号機発電のように水車周辺の短区間の水路範囲内での 運転もありうるが, 本研究では最も実現可能性が高い 1,2 号揚水, 3,4 号発電といった $\mathrm{Y}$ 分岐部を含ん 表- 1 検討対象とした揚水発電所諸元

\begin{tabular}{|c|c|}
\hline 運転開始 & 1996年 (平成8年) \\
\hline 最大出力 & 120万kW (30万kW× 4台) \\
\hline 最大使用水量 & $300 \mathrm{~m}^{3} / \mathrm{s} \quad\left(75 \mathrm{~m}^{3} / \mathrm{s} \times 4\right.$ 台 $)$ \\
\hline 最大揚水量 & $220 \mathrm{~m}^{3} / \mathrm{s} \quad\left(55 \mathrm{~m}^{3} / \mathrm{s} \times 4\right.$ 台 $)$ \\
\hline 有効落差 & $489 \mathrm{~m}$ \\
\hline 導水路 & 円形圧力式, 1条 , 3,355m \\
\hline サージタンク & 制水口型, 1基 \\
\hline 水圧鉄管 & 本管：2条, 条管 : 4条 \\
\hline 放水路 & 円形圧力式 , 2条 , 1,052m \\
\hline 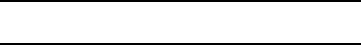 & 制水口型 , 2基 \\
\hline 水車型式 & 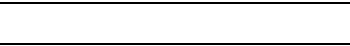 \\
\hline
\end{tabular}

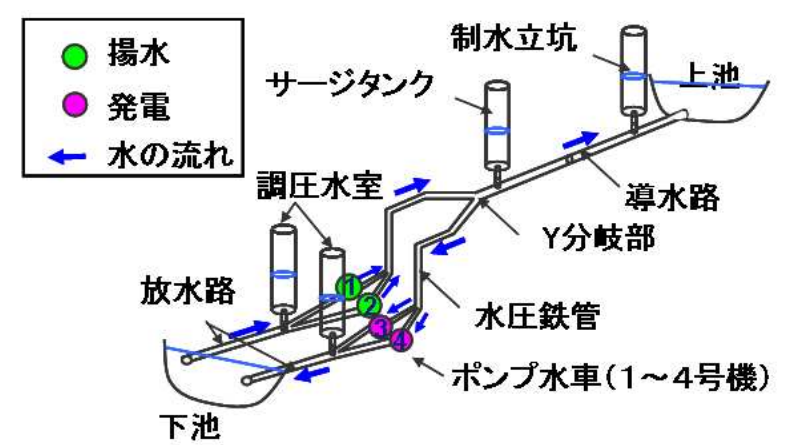

図-1 検討対象とした揚水発電所概要図と同時運転時の流れ

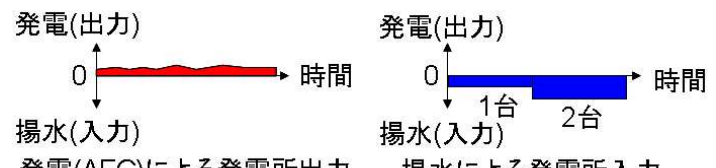

発電(AFC)による発電所出力 揚水による発電所入力

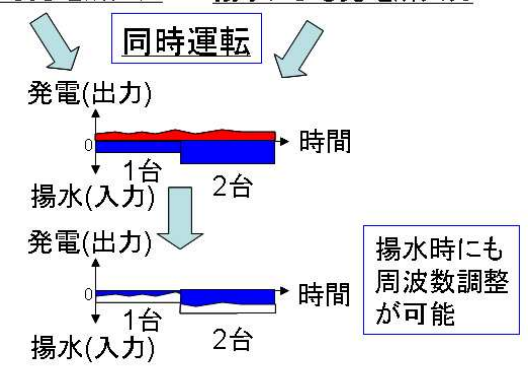

発電(AFC)と揚水同時運転時の発電所入出力

図- 2 揚水・発電同時運転による周波数調整の概要図 
表- 2 同時運転を実施するうえでの水理的課題

\begin{tabular}{|c|c|}
\hline 水理的詥果題 & 内 \\
\hline (1)サージング & 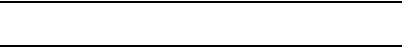 \\
\hline (2)水撃厓 & 発電機急停止時の水撃圧 \\
\hline (3)損失水頭 & 分岐部の損失水頭 \\
\hline (4)キャビテーション & 分岐部のキャビテーション \\
\hline (5)流体力 & 分岐部に作用する流体力 \\
\hline 6)流れのはく離による振動 & 分岐部のはく離による振動 \\
\hline (7)起動恃の流れの変化 & $\begin{array}{l}\text { 運転開始時の水路内の流れの } \\
\text { 変化の追随性 }\end{array}$ \\
\hline 8水路系全体の自励振動 & $\begin{array}{l}\text { 同時運転時の水路の流れの不 } \\
\text { 安定性の検討 }\end{array}$ \\
\hline
\end{tabular}

だ長区間の水路範囲の組み合わせに絞って検討すること とした . 以下に(1)〜3の3項目の検討結果を示す .

\section{4.サージングに関する検討}

図-1に示したような同時運転を実施しているときに発 電急停止 (負荷遮断) ・揚水急停止 (入力遮断) 力発生 した場合のサージタンクの最高・最低水位について検討 した . 鶴巻らはAFC運転時の水力発電所におけるサージ ング水位変動特性の理論解を明らかにしているが7), 光 の研究で前提としている運転方法は通常の発電運転であ り，本研究のような同時運転は対象としていない，光こ で , 式(1a)〜 (1g)に示す制水口型のサージングの基礎式 を用いた逐次計算により同時運転時におけるサージタン ク内の水位変動量を評価した .

· 取水口〜制水立坑

$$
\begin{aligned}
& \frac{d H_{1}}{d t}=\frac{A_{1} \cdot V_{1}-A_{2} \cdot V_{2}}{F_{1}} \\
& \frac{d V_{1}}{d t}=\frac{H_{0}-H_{1}-C_{1} \cdot V_{1} \cdot\left|V_{1}\right|}{L_{1} / g}
\end{aligned}
$$

・制水立坑〜サージタンク

$$
\begin{gathered}
\frac{d H_{2}}{d t}=\frac{A_{2} \cdot V_{2}-Q_{\text {sum }}}{F_{2}} \\
\frac{d V_{2}}{d t}=\frac{H_{1}-H_{2}-C_{2} \cdot V_{2} \cdot\left|V_{2}\right|-k_{2}}{L_{2} / g} \\
k_{2}=\frac{\left(A_{2} \cdot V_{2}-Q_{\text {sum }}\right)\left|A_{2} \cdot V_{2}-Q_{\text {sum }}\right|}{2 g\left(C_{d} \cdot F_{p}\right)^{2}} \\
C_{d}= \begin{cases}C_{\text {din }} & \left(A_{2} \cdot V_{2}-Q_{\text {sum }}\right) \geq 0 \\
C_{\text {dout }} & \left(A_{2} \cdot V_{2}-Q_{\text {sum }}\right)<0\end{cases} \\
Q_{\text {sum }}=Q_{p 1}+Q_{p 2}+Q_{p 3}+Q_{p 4}
\end{gathered}
$$

ここに, $\mathrm{H}_{0}, \mathrm{H}_{1}, \mathrm{H}_{2}$ : 上池 , 制水立坑 , サージタンクの 水位, $\mathrm{F}_{1}, \mathrm{~F}_{2}$ : 制水立坑, サージタンクの断面積, $\mathrm{V}_{1}, \mathrm{~V}_{2}$ : 取水口から制水立坑間の導水路流速，制水立坑か
らサージタンク間の導水路流速， $\mathrm{C}_{1}, \mathrm{C}_{2}$ : 取水口から制 水立坑間の損失水頭係数，制水立坑からサージタンク間 の損失水頭係数， $A_{1}, A_{2}$ : 取水口から制水立坑間の導水路 断面積, 制水立坑からサージタンク間の導水路断面積, $\mathrm{L}_{1}, \mathrm{~L}_{2}$ : 取水口から制水立坑間の導水路延長，制水立坑か らサージタンク間の導水路延長， $C_{\text {din }}, C_{\text {dout }}$ : 導水路 サージタンクの流入・流出時の制水口係数, $\mathrm{F}_{\mathrm{p}}$ : 制水口 断面積, $Q_{p 1} \sim Q_{p 4}, Q_{\text {sum }}: 1 \sim 4$ 号機の流量, 導水路内流 量 (発電方向を正，揚水方向を負) である.なお，使用 した計算プログラムは運転開始時の試験における実測結 果を用いて, 光の水位およびサージング波形の再現性が 良好であることを確忍している . 本検討では前述したよ うに 1,2 号揚水，3,4号発電の組み合わせの同時運転を対 象としているため，水車より下流の放水路については水 の流れは設計どおりである .このため , サージングの検 討は水車よりも上流側を対象とした .

$\mathrm{AFC}$ 運転時の発電流量は, 常に変化する電力需給に応 じて変化するため, サージタンク水位の変動が最大とな る流量波形 , 周期をトライアルで決定した . また , 危険 側を想定するため，2台最大揚水 $\left(110 \mathrm{~m}^{3} / \mathrm{s}\right)$ と2台 $\mathrm{AFC}$ 運転 $\left(150 \mathrm{~m}^{3} / \mathrm{s} \sim 60 \mathrm{~m}^{3} / \mathrm{s}\right)$ の同時運転を検討条件として いる.このときの同時運転時の流量変動波形およびサ一 ジタンク水位の経時変化を図 3 , 図-4に示す .このよう にサージタンク内の水位か変動をしているときに負荷遮 断, 入力遮断した場合の最高水位・最低水位を検討した . 最高水位を検討するための遮断パターンとして，水位 上昇量が大きいとされる負荷遮断の場合および入力遮断 によるサージング摇れ戻しか負荷遮断により増幅される 場合として，(1)同時運転中に2台負荷遮断（揚水は継

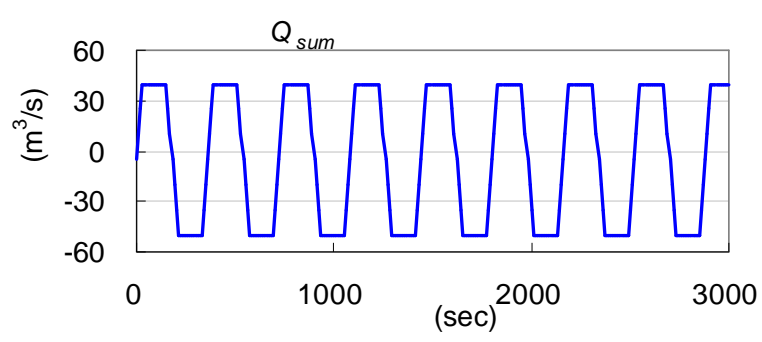

図-32台揚水，2台発電 (AFC運転) 中の導水路内流量

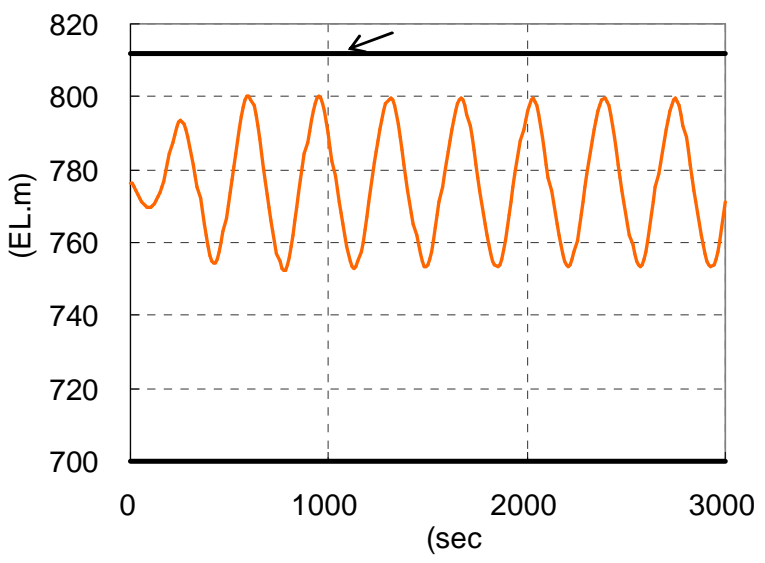

図-4 2台揚水, 2台発電 (AFC運転) 中の 導水路サージタンク水位変動 
続)と (2)同時運転中に2台入力遮断し一定時間後に2台 負荷遮断という2ケースを選定した．各ケースの遮断時

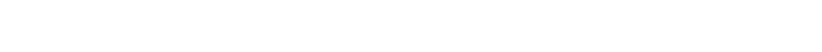
た . このときのサージタンク内の水位変動の計算結果を 图-5に示す. 最高水位はパターン(1)て発生し, 光の水位 はサージタンク天端よりも3m程度低い高さであった 。 最低水位を検討するための遮断パターンとしては(1)同時 運転中に2台入力遮断 (発電は継続) と(2)同時運転中に2 台入力遮断し一定時間後に2台負荷遮断という2ケースを 選定し, 最高水位の検討と同樣に遮断時刻はトライアル で決定した .このときのサージタンク内の水位変動の計 算結果を图-6に示す.最低水位はパターン(1)て発生し， 弚の水位はサージタンク基盤よりも $3 \mathrm{~m}$ 程度高い值で あつた 。

以上の検討により，比較的大きい流量変動条件におい ても , 同時運転時の負荷・入力遮断によるサージタンク 水位は既設サージタンク内に収納されることがあきらか となった .なお，設定する余裕を大きくしたい場合には， 上池貯水池の水位に応じてAFC運転を実施しないなどの 水位制限の措置をとればよい .

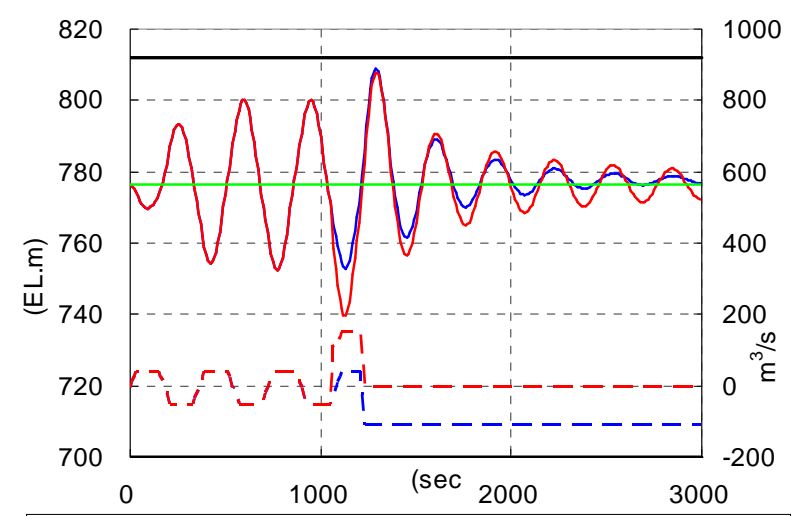

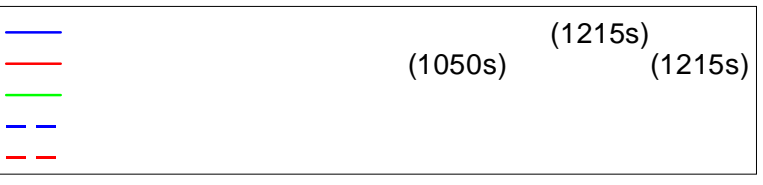

図-5 同時運転中に遮断した場合の最高水位の検討結果

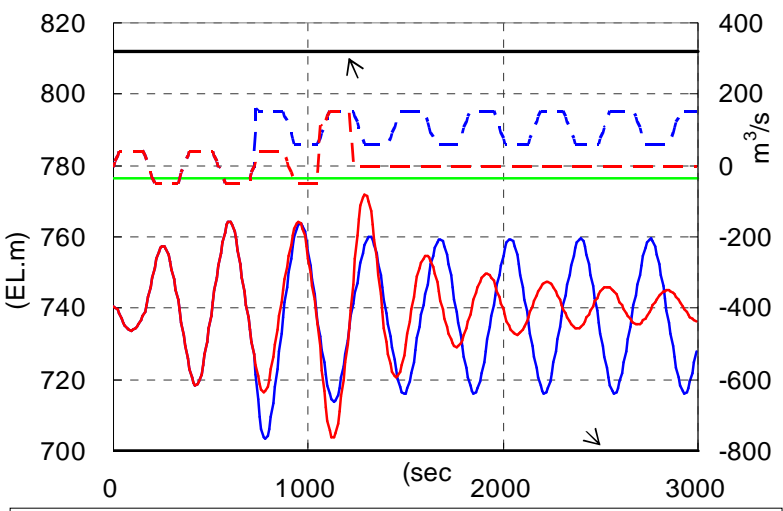

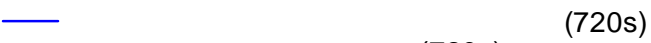

一水位 遮断口田(2)入力遮断(720s) $\rightarrow$ 負荷遮断(870s)

—上池水位

- - 導水路流量 遮断口田(1)発電継続+入力遮断

- 導水路流量 遮断口回 (2) 入力遮断 $\rightarrow$ 負荷遮断

図-6 同時運転中に遮断した場合の最低水位の検討結果

\section{5 ．水撃圧に関する検討}

水力発電所では, 負荷遮断や入力遮断などの使用水量 の増減に応じて, 導水路内て水撃圧力発生する.このた め, 同時運転時における水撃圧をあらかじめ評価してお く必要がある.一般水力発電所では, 例えばAllieviの式 ${ }^{8)}$ などにより水撃圧を評価することが多いが，この揚水 発電所の水車はポンプ水車であるため, 遮断時に水車が 複雑な挙動をすることから，兴の手法を用いることがで きない . ポンプ水車では, 負荷遮断時にはまず水車回転 数が上昇し無拘束速度に至ると回転速度力安定し, 兴の 後, 流量が屰転し揚水状態になる。一方, ポンプ入力遮 断時には, 急速に揚水流量か低下し, 弚の後発電方向に 逆流する.このような複雑な挙動を予測するため, 遮断 時のポンプ水車の動きを境界条件に入れた特性曲線法に より水撃圧を検討した . 水撃圧の評価に使用した基礎式 は式(2a),(2b)に示すとおりである . 具体的な計算方法は 参考文献”による．

$$
\begin{aligned}
& \left.\begin{array}{l}
\frac{a}{g} \frac{d H}{d t}+\frac{d V}{d t}+\frac{g}{a} V \sin \alpha+\frac{f V V \mid}{2 D}=0 \\
\frac{d x}{d t}=V+a
\end{array}\right\} C+ \\
& \left.-\frac{a}{g} \frac{d H}{d t}+\frac{d V}{d t}-\frac{g}{a} V \sin \alpha+\frac{f V|V|}{2 D}=0\right\} C \\
& \frac{\mathrm{dx}}{\mathrm{dt}}=\mathrm{V}-\mathrm{a}
\end{aligned}
$$

ここに，H：水撃水頭（位置水頭+圧力水頭）， V : 流速， $a$ : 水撃圧の伝播速度, $f$ : 摩擦損失係数, $D$ : 管 径, $g$ : 重力加速度である. 水車の回転数は式(3) と水車 特性曲線から計算する。

$$
\frac{2 \pi}{60} \frac{G D^{2}}{4 \mathrm{~g}} \frac{\mathrm{dN}}{\mathrm{dt}}=\mathrm{T}
$$

ここに, $G D^{2}:$ はずみ車効果， $T:$ 水車卜ルク $, N:$ 水 車回転数である. ガイドベーン開度, 水車上下流圧力, 回転数, トルクから特性曲線法を用いて水撃圧を算出す る.計算に必要なポンプ水車の特性は建設時の水車模型 実験により得られたものを用いた .

水撃圧の計算には水車の上下流の水圧が必要であるた め, 上池から下池までのサージタンク , 調圧水槽を含む 全水路を管路網として構成した。

$\mathrm{AFC}$ 運転ではない通常発電時 $\left(\mathrm{Q}=300 \mathrm{~m}^{3} / \mathrm{s}\right.$ で一定) の ときに発電停止した場合の水撃圧を計算すると図-7のと おりであり，水車位置での最大水頭は713mであった .

次に，同時運転時の水撃圧を計算した . 同時運転時の 水撃圧の遮断条件はAFC運転中にサージングで最高水位 か甡じる条件である2台発電停止 (揚水は継続) とし， 停止時刻は前述のサージンク検討でサージタンク内の最 


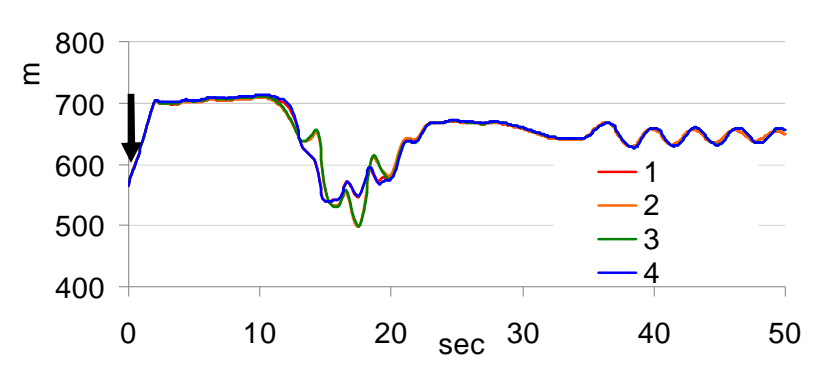

図-7 通常運転時の水撃圧 (水車位置水頭)
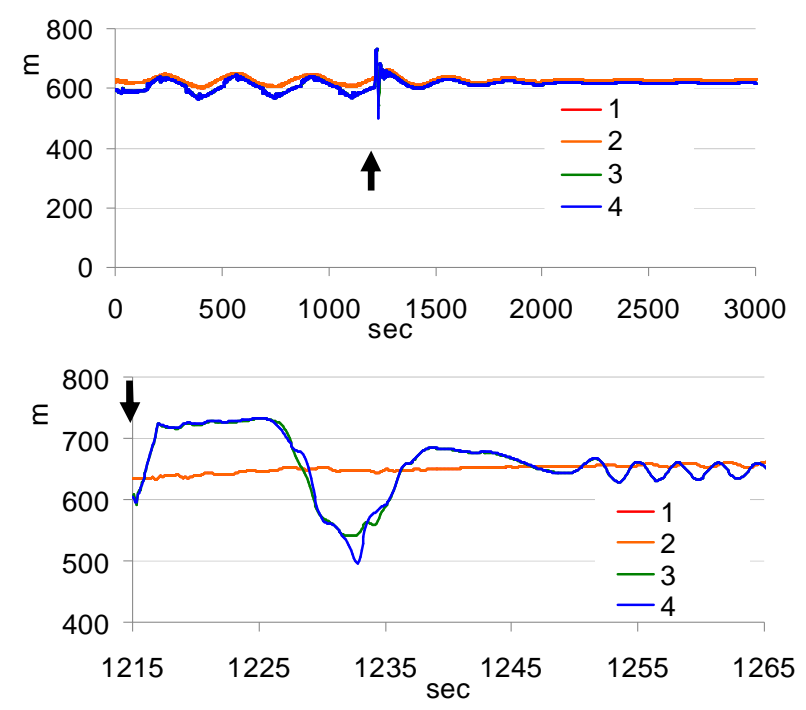

図-8同時運転時の水撃圧 (水車位置水頭) (上段：全時系列，下段：遮断時付近拡大)

高水位が最大となるようにトライアル検討した結果であ る1215secとした .このときの水車位置の水頭の時系列 を図-8に示す . 同時運転のときの水車位置の最大水頭は 733mであった .

$\mathrm{AFC}$ 運転中の負荷遮断側の水撃圧波形形状は通常運転 時の波形と類似しているが, 最大值は通常運転時の值よ りも20m大きい .これは，同時運転時は取水口〜Y分岐 部までの導水路の流量が-50〜 $40 \mathrm{~m}^{3} / \mathrm{s}$ と通常運転時の $300 \mathrm{~m}^{3} / \mathrm{s}$ 上りもかなり小さいことから，この区間の損失 水頭が小さく, 結果的に静水圧が通常運転時を上回るた めである . ただし , 同時運転と通常運転の差はとれほど 大きい值ではなく，同時運転時に上池に制限水位を設定 することにより対応か可能と考えられる . また図-8から， 揚水側の水撃圧の変化は小さく，発電側 $(3,4$ 号機) の 遮断か揚水側 $(1,2$ 号機) に与える影響は小さいことが わかる .

\section{6 . 損失水頭に関する検討}

図-1に示すとおりこの発電所では導水路サージタンク の下流にY分岐部があるが，同時運転を実施した場合に はこれまでの設計では考慮していない方向の流れが分 岐部に生じ損失水頭が過大になることか懸念される .
そこで，この同時運転時におけるY分岐部の損失水頭 を3次元流体解析により評価した .なお，前述したよう に本検討では 1,2 号揚水，3,4号発電という運転方法を対 象としたため，損失水頭の検討においては導水路サージ タンク直下のY分岐部のみを対象とした . 数值解析には , 非構造格子系の3 次元熱流体解析ソフトウェア SCRYU/Tetra（V8）を使用した .上流側のトンネル湾曲 およびY分岐後の鉄管の曲がりを考慮するために，解析 範囲はY分岐部より取水口側 $280 \mathrm{~m}$ から分岐後下流 $390 \mathrm{~m}$ までとした . 解析モデルの全体図は図-9に示すとおりで ある.なお，解析モデルでは分岐部の整流板や分岐部下 流の鉄管弁などを忠実に再現した . 解析用の平均的な格 子幅は, 水路全体は約 $16 \mathrm{~cm}, Y$ 分岐部は約 $8 \mathrm{~cm}$ とした . Y分岐部の平均的な格子幅は下流側鉄管直径 $5 \mathrm{~m}$ の約 $1 / 60$ であり，充分な分解能を有している。なお，計算格子数 は約6500万である . 損失水頭を評価するための解析ケー スとして, 揚水量は2台揚水時の最大流量 $\left(-110 \mathrm{~m}^{3} / \mathrm{s}\right)$ で 一定としAFC運転をする発電側の流量を $25 \sim 150 \mathrm{~m}^{3} / \mathrm{s}$ ま て変化させた表-3のケースを設定した . 解析は定常解析 とし，乱流モデルは標準k-€ モデルを用いた .

解析結果から，発電側流量 $100 \mathrm{~m}^{3} / \mathrm{s}$ の場合のY分岐部 (水路底から $1 \mathrm{~m}$ 位置) のベクトル図を図-10に示す. 分 岐部の整流板下流て录漓隹力㲎じていることがわかる.解 析結果からY分岐部の損失水頭を以下のように評価した . 图-11に示す面A,B,C面における断面平均圧力，断面平均 流速から各断面の全水頭を算出し, 最大発電時

(H300) はA面を，最大揚水時（Y220）はB,C面を，同 時運転の場合はB面を基準とした場合の全水頭の低下量

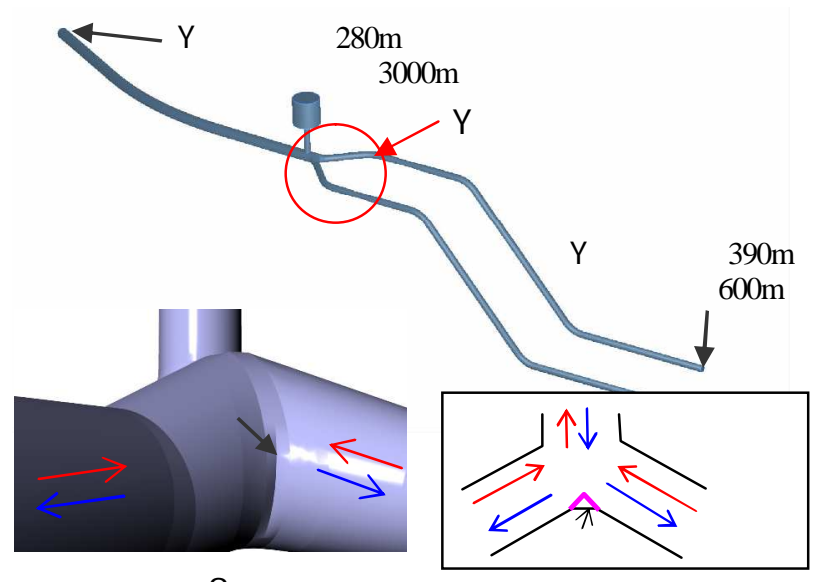

図-9 損失水頭を評価するための解析モデル

表- 3 損失水頭を評価するためめ解析ケース

\begin{tabular}{|c|c|c|c|c|}
\hline 運転 & ケース & $\begin{array}{c}\text { 揚水側 } \\
\text { 流量 }\end{array}$ & $\begin{array}{c}\text { 発電側 } \\
\text { 流量 }\end{array}$ & Y分岐部流況 \\
\hline \multirow{4}{*}{ 同時 } & $\mathrm{Y} 110 \mathrm{H} 150$ & $110 \mathrm{~m}^{3} / \mathrm{s}$ & $150 \mathrm{~m}^{3} / \mathrm{s}$ & 合流 \\
\cline { 2 - 5 } 運転 & $\mathrm{Y} 110 \mathrm{H} 100$ & $110 \mathrm{~m}^{3} / \mathrm{s}$ & $100 \mathrm{~m}^{3} / \mathrm{s}$ & 分岐 \\
\cline { 2 - 6 } & $\mathrm{Y} 11 \mathrm{H} 75$ & $110 \mathrm{~m}^{3} / \mathrm{s}$ & $75 \mathrm{~m}^{3} / \mathrm{s}$ & 分岐 \\
\cline { 2 - 5 } & $\mathrm{Y} 110 \mathrm{H} 50$ & $110 \mathrm{~m}^{3} / \mathrm{s}$ & $50 \mathrm{~m}^{3} / \mathrm{s}$ & 分岐 \\
\cline { 2 - 5 } & $\mathrm{Y} 110 \mathrm{H} 25$ & $110 \mathrm{~m}^{3} / \mathrm{s}$ & $25 \mathrm{~m}^{3} / \mathrm{s}$ & 分岐 \\
\hline
\end{tabular}


を損失水頭として評価した .このため, 得られる損失水 頭は各面間の摩擦，曲がり損失等を含めた值になる．分 岐ケースの損失水頭はB-C間で最大 $1.0 \mathrm{~m}$ 程度 , B-A間で 最大 $0.5 \mathrm{~m}$ 程度であった . また , 合流ヶース $(\mathrm{Y} 110 \mathrm{H} 150) の$ 損失水頭は最大 $1.0 \mathrm{~m}$ 程度であつた，通常運転時の損失水 頭設計值が約 $34 \mathrm{~m}$ であり同時運転分岐部の損失水頭は乥 の3\%程度にすぎないことから，同時運転のY分岐部の損 失水頭は運転上支障がない程度の大きさであるといえる．

分岐ケースの損失水頭から損失係数を求めた結果を

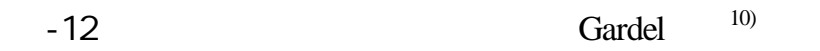
る損失係数を図-12に示す. 分岐ケースの解析による同 時運転時の損失係数の值はGardelの式と同程度であった . 同時運転時のサージングや水撃圧の詳細検討で行う1次 元解析に分岐損失を考慮する場合にはこの損失係数を用 いることができる .

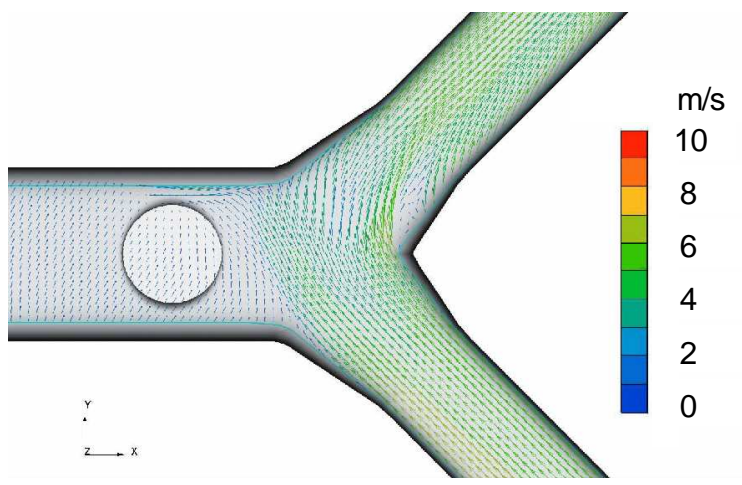

図 10 同時運転時 (ケースY110Hツ0) のY分岐部ベクトル图

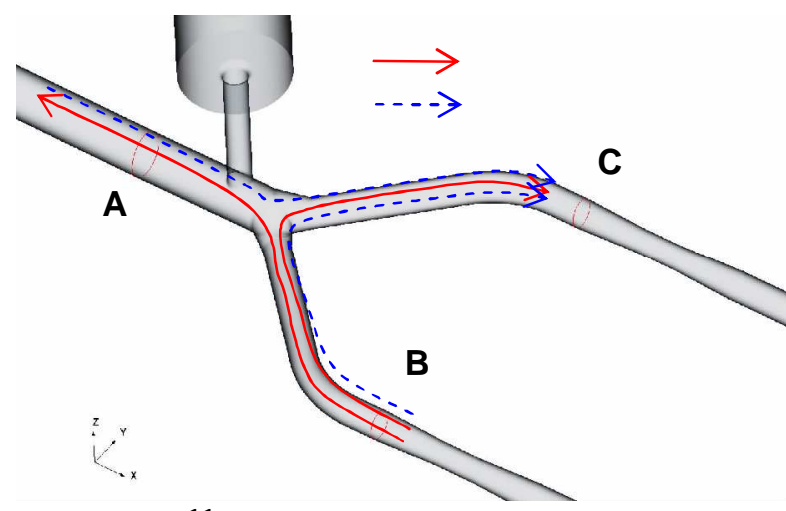

図-11 損失水頭を評価するための断面位置

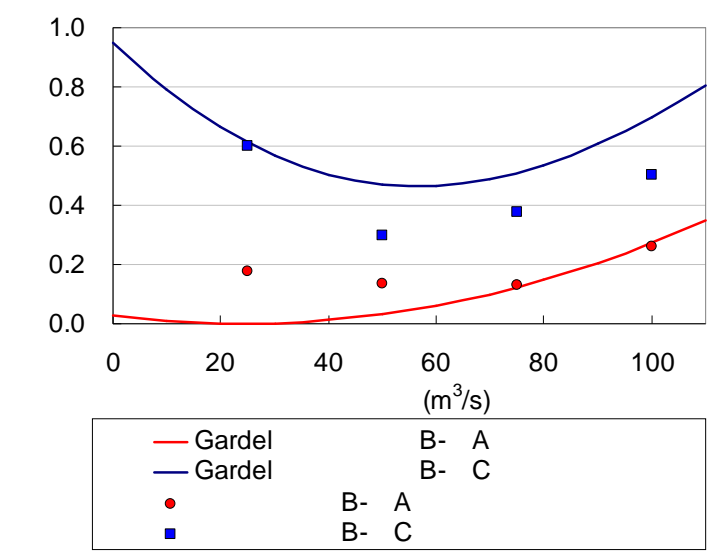

图-12 解析とGar del の式による分岐部損失水頭
7 .おわりに

本研究では, 複数台の定速機のポンプ水車および水路 途中にY分岐部を有する既設の揚水発電所において同時 運転を実施した場合の水理的課題について8項目を抽出 し, 弚のうち基本的な3つの検討を行い以下の結論を得 た。

（1）同時運転によるAFC運転を実施した場合の流量変 動条件においても，負荷・入力遮断によるサージタ ンク水位は既設のサージタンク内に収納される .

（2）同時運転中の負荷遮断側の水撃圧波形は通常運転 時の波形と類似しているが，最大值は通常運転時の 值よりも20m大きい . これは導水路における損失水 頭が小さく, 結果的に静水圧が通常運転時を上回る ためである .ただし，弚の差は同時運転時に上池に 制限水位を設定することにより対応か河能な程度の 値である。

（３）同時運転時におけるY分岐部の損失水頭は総損失 水頭の $3 \%$ 程度であり，運転上支障がない程度の大 きさと考えられる .

（4）水理的な基本検討における解決力涃難な課題はな く，同種の既設揚水発電所における揚水・発電同時 運転の可能性が見出された .

\section{参考文献}

1) 例えば, 電気事業連合会編纂: 電力系統, 電気事業講座 7 pp.27-37,株式会社エネルギーフォーラム , 2007.2.

2) 例えば, 電気事業連合会編纂：電力系統, 電気事業講座 7, pp.193-194, 株式会社エネルギーフォーラム , 2007.2.

3）例えば，エレクトリックエナジー史 , pp.135-138 , オーム社, 1989.12.

4) 大河内発電所運開, 電力土木, No259, pp200-201,1995.9.

5) 西中廣志, 米津和哉, 丹原秀大 : 奥多々良木発電所 可变速 化に伴う横坑拡幅工事の概要，電力土木， No.354, pp.25-29, 2011.7.

6) 吉岡一郎 : ヨーロッパにおける再生可能エネルギーおよび放 射性廃菓物処理に関する調査 - 第33回電力土木技術海外調査 事業報告, 電力土木，No.352，pp.141-146,2011.3.

7) 鶴巻有一郎 , 板倉正和 : 自動周波数制御用水力発電所におけ るサージングの研究,土木学会論文集No.509/ II -30,pp.111-119， 1995.2.

8) 例えば社団法人土木学会編：水理公式集 [平成11年度 版],p279,1999.11.

9) 社団法人電気協同研究会 : 水車・発電機の水圧変動率及び速 度变動率,第40巻,第2号,pp.42-45,1984.7.

10)例えば社団法人土木学会, 水理公式集昭和38年増補改訂版， pp.153-157, 1967.

(2012. 9. 30受付) 